RGSA - Revista de Gestão Social e Ambiental

Jan. - Abr. 2010, V.4, No.1, p. 137-158 ${ }^{1}$

www.gestaosocioambiental.net

\title{
PRÁTICAS DE GESTÃO AMBIENTAL EM UM CONDOMÍNIO HORIZONTAL FECHADO DA GRANDE NATAL-RN: UM ESTUDO SOBRE A PERCEPÇÃO DE CONDÔMINOS
}

\author{
Ana Flávia Oliveira de Almeida \\ Especialista em Gestão Ambiental (IFRN); Bacharel em Comunicação Social (UFRN) e Tecnóloga em \\ Meio Ambiente (IFRN). E-mail: ambienteana@gmail.com

\section{Handson Cláudio Dias Pimenta} \\ Professor do Instituto Federal do Rio Grande do Norte - IFRN; Mestre em Ciências em Engenharia de \\ Produção, Especialista em Gestão Ambiental (UFRN); Engenheiro de Produção (UFRN); Coordenador do \\ Núcleo de Estudos em Sustentabilidade Empresarial. E-mail: handson.pimenta@ifrn.edu.br
}

\section{Resumo}

Os condomínios horizontais fechados ganham cada vez mais adeptos desse tipo de moradia, no entanto observa-se que nem sempre a concentração desse tipo de moradia se dá de forma ordenada ambientalmente. Destaca-se ainda, que muitos aspectos ambientais significativos de um condomínio são ocasionados pela ausência de consciência e atitude inadequada dos condôminos frente ao gerenciamento destes. Assim, este trabalho analisa o nível de consciência e atitudes ambientais, além da aceitação por parte dos moradores quanto à implementação de práticas de gestão ambiental no condomínio Jardim Europa, situado no município de Parnamirim-RN. A pesquisa utilizou como instrumento de coleta de dados, um questionário estruturado em escala do tipo Likert, com questões fechadas, contemplando 27 variáveis e subdividida em 04 grupos (Consciência, Atitude, Programas Ambientais e Perfil). As técnicas estatísticas utilizadas para a análise de dados foram descritivas e de agrupamento (cluster). Os resultados indicam que os condôminos apresentam um elevado grau de instrução, no entanto ainda existe uma lacuna quanto à consciência e atitude ambiental que em alguns casos confronta com a preocupação financeira. No entanto, quando um recurso ambiental relaciona-se com o financeiro, como no caso da energia, notadamente há um maior número de pessoas empenhadas em reduzir os gastos.

Palavras-chave: gestão ambiental, consciência e atitude ambiental, aspectos e impactos ambientais.

\begin{abstract}
The closed horizontal condominiums has been gained more fans of this kind of housing, however there is not always such a concentration occurs in an environmentally ordered way. In addition, many significant environmental aspects of a condominium are caused by lack of awareness and bad attitude front of the residents regarding management of these. Thus, this paper analyzes the awareness and attitudes level, as well as acceptance by residents about the implementation of an environmental management pratices in Jardim Europa, located in the municipality of Parnamirim

\footnotetext{
${ }^{1}$ Recebido em 16.12.2009. Aprovado em 20.03.2010. Disponibilizado em 28.04.2010. Avaliado pelo sistema double blind review
} 
- RN. The research used as a tool for data collection, a structured questionnaire in Likert scale, with closed questions, covering 27 variables and divided into 04 groups (Awareness, Attitude, Environmental Programs and Social profile). Statistical techniques were used for data analysis and cluster analysis. The results indicate that the residents had a high education level, however there is a gap regarding the environmental awareness yet that in many cases confronted with the attitude to establish a sustainable housing environment. However, when an environmental resource is related to the financial issue, like energy, especially there is a greater number of people committed to reducing spending.

Keywords: environmental management, environmental awareness and attitude, environmental aspects and impacts.

\section{INTRODUÇÃO}

O meio urbano se desenvolveu, na maioria das cidades do Brasil e do mundo, por meio de um processo acelerado e desordenado. Este processo, juntamente com a inexistência e/ou a não aplicação de políticas públicas de planejamento urbano e social, originou uma realidade em desacordo com os conceitos de sustentabilidade ambiental e harmonia social, desencadeando os atuais problemas enfrentados pela concentração urbana irregular.

Ao segregar espacialmente as cidades, os condomínios horizontais fechados refletem harmonia social, mas poucas vezes esse modelo se ergue atento aos aspectos ambientais relacionados à ocupação urbana. A construção civil apresenta a moradia em condomínios horizontais fechados como um núcleo à parte, onde se aplicam de forma planejada as formas de conter os reflexos da desordem urbana das cidades.

O conceito de segurança aliado ao conforto residencial gerado pelos condomínios horizontais fechados tem gerado uma intensa demanda de mercado, confrontando-se perceptivelmente com a falta de espaços para novas construções de casas em Natal-RN. A solução para essa demanda acarretou um intenso crescimento imobiliário no bairro de Nova Parnamirim, localizado em Parnamirim (RN), município pertencente a região da grande Natal. Entre agosto de 2008 e julho de 2009, o crescimento da população de Parnamirim (RN) foi proporcionalmente três vezes maior que o de Natal-RN. Enquanto na capital a população passou de 798.065 para 806.203, representando um crescimento de $1,01 \%$, Parnamirim aumentou de 178.819 habitantes para 184.222, que equivale a um aumento de 3,02\% na população (Duarte, 2009).

Diante dessa realidade, essa pesquisa pretende avaliar a percepção relacionada ao nível de consciência e a atitude frente aos aspectos e impactos ambientais de moradores do condomínio Jardim Europa, localizado em uma das principais avenidas do bairro de Nova Parnamirim. Para tanto, foram aplicados questionários com os condôminos utilizando o método de pesquisa de Survey, com escala do tipo Likert, pelo qual foram analisados os grupos Consciência Ambiental (CA), Atitude Ambiental (AA) e Gestão Ambiental (GA).

O trabalho foi desenvolvido em cinco fases, sendo em seqüência: fundamentação teórica, formulação e aplicação de questionários, tabulação, análise dos dados estatísticos e recomendações ambientais. Também tem como objetivo analisar a aceitação quanto à implementação de práticas de gestão ambiental no condomínio que resultem em uma convivência ambiental sustentável.

A conscientização ambiental tem como ponto de partida não só a visão do gestor do condomínio, mas substancialmente requer iniciativas sustentáveis tomadas por cada morador. Logo, em conjunto, o bem estar ambiental representa uma soma de esforços e alarga-se além do portão 
eletrônico do condomínio quando as práticas do consumo sustentável ganham efeitos na sociedade como um todo.

\section{GESTÃO AMBIENTAL EM CONDOMÍNIOS HORIZONTAIS FECHADOS}

Os tópicos a seguir apresentam os aspectos e impactos identificados em um condomínio horizontal fechado, bem como as práticas sustentáveis recomendadas. Além de abordar temas que fundamentam este trabalho, como Sistema de Gestão Ambiental (SGA), educação ambiental e consumo sustentável.

\subsection{CONDOMÍNIO HORIZONTAL FECHADO: SEUS ASPECTOS E IMPACTOS AMBIENTAIS}

Os condomínios horizontais fechados podem gerar impactos advindos dos aspectos ambientais inerentes a sua construção e funcionamento. Segundo a Norma ISO 14001:2004, no item 3.6, aspecto ambiental é o elemento das atividades ou produtos ou serviços de uma organização que pode interagir com o meio ambiente.

Os impactos negativos podem se desdobrar a partir dos aspectos ambientais maus gerenciados. Assim, observa-se uma relação de causa e conseqüência advindas da construção e funcionamento de um condomínio horizontal fechado. Como exemplo, quando uma construtora está em busca de um terreno propício para construção deve observar aspectos de uso e ocupação do solo, entre outros requisitos. Os quadros 01 e 02 , respectivamente, apresentam os aspectos e os impactos identificados no espaço ocupado pelo condomínio nas fases de construção e habitação. Eles apresentam na primeira coluna uma relação dos aspectos ambientais de um condomínio. A segunda coluna relaciona os impactos que podem se desdobrar a partir de um mau gerenciamento ambiental dos aspectos.

\begin{tabular}{|c|c|c|}
\hline Aspecto (causa) & 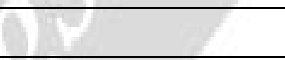 & Impacto (efeito) \\
\hline $\begin{array}{l}\text { Geração de entulho da construção e } \\
\text { demolição (resíduo inerte) }\end{array}$ & $\begin{array}{l}\text { Geração e } \\
\text { disposição }\end{array}$ & Alteração da paisagem \\
\hline Embalagens não reutilizáveis & Geração & $\begin{array}{l}\text { Comprometimento da vida útil de } \\
\text { aterros sanitários }\end{array}$ \\
\hline \multirow{2}{*}{ Água } & Consumo & \multirow{2}{*}{$\begin{array}{c}\text { Comprometimento da disponibilidade } \\
\text { do recurso }\end{array}$} \\
\hline & Vazamento & \\
\hline Água pluvial & Drenagem & $\begin{array}{l}\text { Alagamentos, erosão do solo, } \\
\text { assoreamento de rios e lagos. }\end{array}$ \\
\hline Energia elétrica & Consumo & Redução de Recursos Naturais \\
\hline $\begin{array}{l}\text { Produtos contaminantes (óleo, lubrificante, } \\
\text { graxa, tinta, cimento,gesso, argamassa,etc) }\end{array}$ & Derrame/engraxe & Contaminação da água/do solo \\
\hline Recursos naturais (areia, madeira, gesso) & Consumo & $\begin{array}{c}\text { Comprometimento da conservação de } \\
\text { recursos }\end{array}$ \\
\hline $\begin{array}{l}\text { Resíduos de embalagens de produtos } \\
\text { (cimento, tintas, } \\
\text { solventes) }\end{array}$ & $\begin{array}{l}\text { Geração e } \\
\text { disposição }\end{array}$ & Contaminação do solo \\
\hline $\begin{array}{l}\text { Ruído (martelo-rompedor, bate-estaca, } \\
\text { vibrador, serra circular) }\end{array}$ & Emissão & $\begin{array}{l}\text { Danos à saúde e incômodo à } \\
\text { comunidade }\end{array}$ \\
\hline $\begin{array}{l}\text { Fuligem e gases de efeito estufa causados } \\
\text { pelo trânsito }\end{array}$ & Alteração & Incômodos à comunidade \\
\hline Vegetação & Corte/Supressão & $\begin{array}{l}\text { Alteração da qualidade do solo } \\
\text { (erosão); Danos paisagísticos }\end{array}$ \\
\hline Vibrações (bate-estaca) & Emissão & Incômodo à comunidade \\
\hline
\end{tabular}

(C) RGSA - v.4, n.1, jan./abr. 2010 


\begin{tabular}{|l|c|c|}
\hline Uso e ocupação do solo & Alteração & $\begin{array}{c}\text { Esgotamento de impactos naturais, } \\
\text { influência na área vulnerável } \\
\text { ambientalmente. }\end{array}$ \\
\hline
\end{tabular}

Quadro 1 - Aspectos e impactos na construção do empreendimento

Fonte: Adaptado de: (Almeida \& Filho, 2006)

\begin{tabular}{|c|c|c|}
\hline \multicolumn{2}{|c|}{ Aspecto (causa) } & \multirow{3}{*}{$\begin{array}{c}\text { Impacto (efeito) } \\
\begin{array}{c}\text { Comprometimento da disponibilidade } \\
\text { do recurso }\end{array}\end{array}$} \\
\hline \multirow{2}{*}{ Água } & Consumo & \\
\hline & Vazamento & \\
\hline Água pluvial & Subutilização & Alagamentos, erosão do solo; \\
\hline Resíduos domiciliares & $\begin{array}{l}\text { Geração e } \\
\text { disposição }\end{array}$ & $\begin{array}{l}\text { Contaminação do solo, impacto visual, } \\
\text { proliferação de vetores, etc. }\end{array}$ \\
\hline Óleo de cozinha & Disposição & Poluição das águas. \\
\hline Vegetação & Corte/Supressão & Desconforto térmico. \\
\hline Energia elétrica & Consumo & Redução de Recursos Naturais \\
\hline Sacolas Plásticas & Disposição & Redução de Recursos Naturais. \\
\hline Produtos ecologicamente corretos & Consumo & $\begin{array}{l}\text { Produtos em desacordo com as normas } \\
\text { ambientais podem gerar impactos de } \\
\text { diversas ordens. }\end{array}$ \\
\hline
\end{tabular}

Quadro 2 - Aspectos e impactos no funcionamento do empreendimento

Fonte: Adaptado de: (Almeida \& Filho, 2006)

Portanto, como se pode observar nesses quadros, existem impactos relevantes decorrentes não só na fase de construção, como também na manutenção da rotina do empreendimento.

\subsection{Programas de Gestão Ambiental}

A gestão ambiental pode ser entendida como o conjunto de procedimentos que visam à conciliação entre desenvolvimento e qualidade ambiental. Essa conciliação acontece a partir da observância da capacidade de suporte do meio ambiente e das necessidades identificadas pela sociedade civil ou pelo governo (situação mais comum) ou ainda por ambos (situação mais desejável (Souza, 2000).

Ainda Souza afirma que a gestão ambiental encontra na legislação, na política ambiental e em seus instrumentos e na participação da sociedade suas ferramentas de ação (2000). Conforme listam os quadros 3 e 4, é importante evidenciar as práticas sustentáveis diante dos aspectos préidentificados (Quadros 1 e 2) na fase de construção e funcionamento do condomínio.

\begin{tabular}{|c|c|}
\hline Aspectos & Práticas sustentáveis \\
\hline $\begin{array}{c}\text { Entulhos, produtos } \\
\text { contaminantes, embalagens } \\
\text { de produtos. }\end{array}$ & $\begin{array}{c}\text { Seguir um padrão de descarte antecedidos pelo programa 3 R`s (Reduzir, } \\
\text { Reutilizar e Reciclar) }\end{array}$ \\
\hline Uso e ocupação do solo & Projeto sustentável de implantação do empreendimento \\
\hline Água e Esgoto & $\begin{array}{c}\text { Água: Solicitar a outorga do de direito de uso de recursos hídricos à } \\
\text { Secretaria Estadual de Recursos Hídricos. } \\
\text { Esgotos: reduzir a geração de efluentes; tratamento de esgotos. }\end{array}$ \\
\hline
\end{tabular}

(C) RGSA - v.4, n.1, jan./abr. 2010

www.gestaosocioambiental.net 


\begin{tabular}{|c|c|}
\hline Drenagem de água pluviais & Projetar o empreendimento com vias de escoamento e drenagem \\
\hline $\begin{array}{c}\text { Resíduos sólidos da } \\
\text { construção civil }\end{array}$ & $\begin{array}{c}\text { Disciplinar os resíduos da construção civil através da Resolução } \\
\text { CONAMA N }{ }^{\circ} 307 .\end{array}$ \\
\hline Vegetação & $\begin{array}{c}\text { Plantar espécies nativas adaptadas ao clima observando a adequação do } \\
\text { porte, forma e tamanho de copa compatíveis com o espaço disponível. } \\
\text { Frutos, flores e folhas sem princípios tóxicos perigosos ou espinhos. }\end{array}$ \\
\hline
\end{tabular}

Quadro 3 - Programas de gestão ambiental na construção do empreendimento

\begin{tabular}{|c|c|}
\hline Aspectos & Práticas sustentáveis \\
\hline Consumo de água & $\begin{array}{c}\text { Os condôminos devem adotar práticas de redução do uso da água e } \\
\text { geração de esgoto que otimizem os impactos ambientais gerados. }\end{array}$ \\
\hline Drenagem de água pluviais & $\begin{array}{c}\text { Projetar um sistema de reuso de águas pluviais a ser utilizado na } \\
\text { lavagem das áreas de lazer, irrigação dos canteiros e jardins, reserva para } \\
\text { casos de incêndios, gerando uma expressiva economia no gasto de água } \\
\text { das áreas comuns. }\end{array}$ \\
\hline Geração de resíduos sólidos & Implantação de um programa de Coleta Seletiva \\
\hline Óleo de cozinha & $\begin{array}{c}\text { Armazenar o óleo de cozinha em garrafas do tipo "pet" destinadas à } \\
\text { coleta seletiva. Esse resíduo pode ser reaproveitado na fabricação de } \\
\text { sabão e produção de biodiesel. }\end{array}$ \\
\hline Áreas verdes & $\begin{array}{c}\text { Manutenção (rega, poda,etc) das áreas de jardinagem e incentivo para } \\
\text { plantar espécies frutíferas da flora nativa. }\end{array}$ \\
\hline Energia elétrica & $\begin{array}{c}\text { Adotar práticas de economia do uso de energia elétrica e buscar utilizar } \\
\text { energias alternativas. }\end{array}$ \\
\hline Sacolas Plásticas & $\begin{array}{c}\text { Utilizar sacolas ecológicas (Ecobags) e cobrar dos estabelecimentos } \\
\text { comerciais disponibilizar sacolas oxibiodegradáveis }\end{array}$ \\
\hline $\begin{array}{c}\text { Produtos ecologicamente } \\
\text { corretos }\end{array}$ & $\begin{array}{c}\text { Selecionar os produtos que compra dando preferência aos que menos } \\
\text { contaminam e privilegiando as empresas que investem na preservação } \\
\text { ambiental (Responsabilidade Sócioambiental) }\end{array}$ \\
\hline
\end{tabular}

Quadro 4 - Programas de gestão ambiental no funcionamento do empreendimento

As práticas sustentáveis listadas a partir dos aspectos ambientais nos quadros 03 e 04 orientam a forma ambientalmente correta de agir diante de um bem ambiental.

\subsection{Sistema de Gestão Ambiental (SGA)}

A busca permanente pela qualidade ambiental é um processo de aprimoramento constante do sistema de gestão ambiental global de acordo com a política ambiental estabelecida pela organização.

Existe uma normatização que define claramente os objetivos específicos da gestão ambiental. A norma NBR-ISO 14.001 especifica os principais requisitos de um Sistema de Gestão Ambiental (SGA) que se constitui em um conjunto de procedimentos sistematizados desenvolvidos para que as questões ambientais sejam integradas à administração global de um empreendimento (Braga \& Conejo, 2005).

Dentre os benefícios de um SGA em condomínios pode-se citar: garantia de boas relações com o público e com a sociedade, fortalecimento da imagem perante o mercado, aprimoramento do controle de custos, conservação de matérias-primas e energia, facilidade na obtenção de licenças 
e autorizações, estimulação do desenvolvimento de soluções ambientais e redução dos riscos de poluição ambiental.

\section{METODOLOGIA}

A pesquisa utilizou como instrumento a coleta de dados por meio de questionário, sendo os resultados tratados por técnica de análise de dados.

\subsection{Descrição da área de estudo}

O empreendimento em estudo localiza-se no município de Parnamirim (RN), na Avenida Maria Lacerda Montenegro, (zona UTM 25M, coordenada X 256212, coordenada Y 9347701, DATUNSAD-69) (Figura 1). Possui 49 unidades autônomas residenciais, sendo 43 construídas. As áreas de propriedade exclusiva estão distribuídas em três quadras, medindo ao todo $15.113,20 \mathrm{~m}^{2}$. A área de propriedade comum, que inclui áreas de lazer, guarita, estacionamento para visitantes, vias de circulação interna e área verde, soma $1.335,30 \mathrm{~m}^{2}$. As edificações habitacionais, comunitárias e áreas de circulação comum perfazem uma área total de $20.846,92 \mathrm{~m}^{2}$.

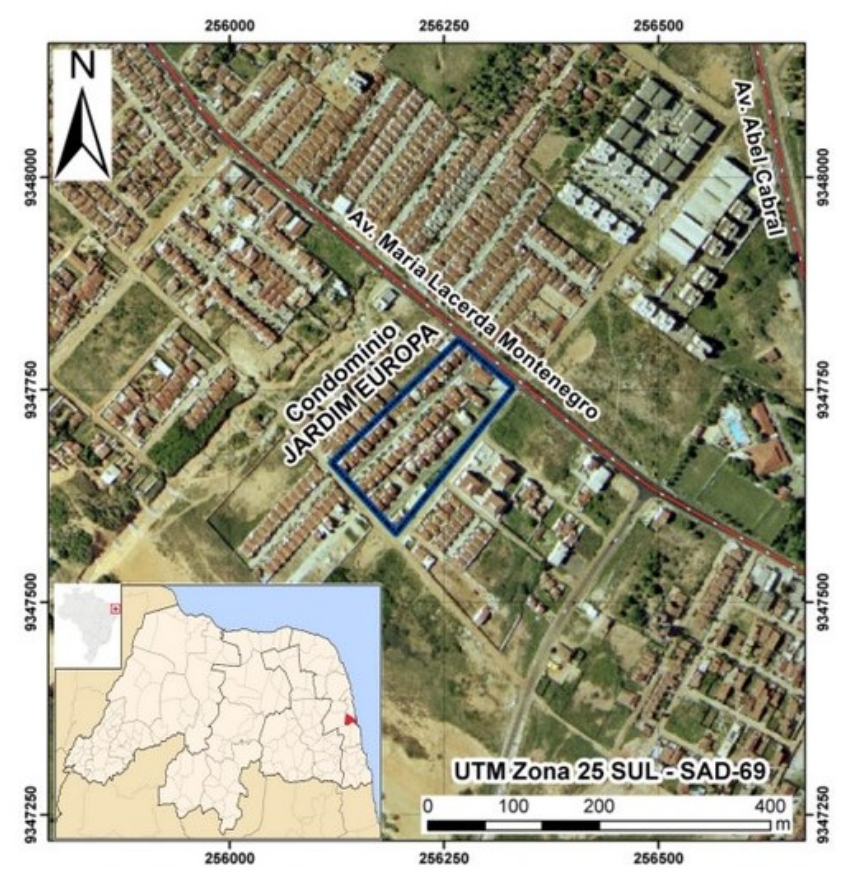

Figura 1 - Mapa de localização do condomínio Jardim Europa.

No condomínio não existem programas ambientais consolidados, como coleta seletiva e reuso de águas pluviais. O abastecimento de água é feito pela Companhia de Águas e Esgoto do Rio Grande do Norte (CAERN) através da exploração de poços tubulares e pelo manancial da lagoa do Jiqui, pertencente à Bacia Hidrográfica do rio Potengi. Os efluentes sanitários são tratados via tanque séptico, e lançado no solo através de sumidouros, assim como em $98 \%$ do município de Parnamirim. Destaca-se que o empreendimento não possui licença ambiental.

Os resíduos sólidos são coletados sem a separação dos materiais em cada casa por um funcionário do condomínio e encaminhados para a coleta do município. Estes resíduos são enviados para a Usina de Triagem, localizada no bairro de Cidade Nova. 
A escolha deste condomínio se justifica, inicialmente pela acessibilidade à busca de informações, além do interesse do síndico em implantar, a partir desta análise, ações de gestão ambiental, o que desencadeou .

\subsection{Instrumento de coleta de dados, população e amostra}

Esta pesquisa classifica-se como sendo descritiva do tipo Survey, visto que este tipo de estudo busca obter dados ou informações sobre as características, ações ou opiniões de determinado grupo de pessoas por meio de questionário como instrumento de pesquisa (Carvalho \& Silva, 2009).

O procedimento utilizado para a realização da coleta de dados, sustentou-se na definição e uso de um questionário contendo perguntas com graus de opinião (0-5), de acordo com a escala do tipo Likert, cuja qualificação das respostas possíveis se organizam em grupos para cada questionamento aplicado. A opção em se utilizar à escala Likert está na vantagem desse procedimento levar a uma variabilidade, o que admite que os respondentes se expressem em termos de graus de opinião sobre a questão tratada no questionário de pesquisa (Chiamenti, 2003).

Foram utilizadas 27 variáveis distribuídas em três grupos ambientais, sendo estes: Consciência Ambiental (CA), Atitude Ambiental (AA) e Gestão Ambiental (GA). As respostas dos grupos CA e GA foram analisadas e quantificadas de acordo com a legenda de resposta do questionário aplicado na pesquisa, conforme tabela 1 . As variáveis do grupo AA foram apresentadas em uma escala descritiva relacionada às práticas ambientais. Os graus de opinião formulados obedecem o nível da escala do tipo Likert atribuída aos demais grupos.

Tabela 1 - Escala do tipo Likert aplicada no questionário

\begin{tabular}{|c|c|c|c|c|c|c|}
\hline Valor & 0 & 1 & 2 & 3 & 4 & 5 \\
\hline Descrição & $\begin{array}{c}\text { Sem } \\
\text { opinião }\end{array}$ & $\begin{array}{c}\text { Discordo } \\
\text { totalmente }\end{array}$ & $\begin{array}{c}\text { Discordo } \\
\text { em parte }\end{array}$ & $\begin{array}{c}\text { Não sei/ } \\
\text { tanto faz }\end{array}$ & $\begin{array}{c}\text { Concordo } \\
\text { em parte }\end{array}$ & $\begin{array}{c}\text { Concordo } \\
\text { totalmente }\end{array}$ \\
\hline
\end{tabular}

Destaca-se que a resposta "Não sei/tanto faz" e "Sem opinião" possuem características distintas. "Não sei/tanto faz" remete a uma resposta vazia de informação, mas que posiciona o respondente dentre as outras opções de resposta. "Sem opinião" demonstra que o respondente não quer se posicionar por não ter qualquer opinião ou se comprometer com as alternativas apresentadas.

Conforme Walman e Schneider (2000), a consciência é fundamental para conservação e manutenção da natureza, pois tendo em mente que o mundo conta com recursos limitados, as pessoas fazem parte de um contínuo movimento de preservação do meio ambiente. O grupo Consciência Ambiental (CA) soma nove variáveis que pretendem extrair do respondente o nível de percepção/consciência ambiental sobre os temas tratados. É formado pelas seguintes variáveis de opinião: Op_imp (impactos ambientais causados pelo condomínio); Op_ca (impacto ambiental causado pelo consumo de água no condomínio); Op_ce (impacto ambiental causado pelo consumo de energia no condomínio); Op_ef (impacto ambiental causado pelo destino de efluente); Op_gr (impacto ambiental causado pela geração de resíduos sólidos); Op_av (impacto ambiental causado pelo manutenção da área verde - jardinagem); Op_ap (impacto ambiental causado pelas águas pluviais); Op_oc (impacto ambiental causado pelo descarte de óleo de cozinha) e Imp_amb (Importância atribuída aos cuidados ambientais no condomínio).

O estudo das atitudes e das preferências constitui um objetivo primordial para a compreensão do comportamento. Segundo Bertolini e Possamai (2009), uma atitude é uma predisposição para 
reagir a uma situação com uma resposta específica, e esta pode ser negativa ou positiva. Atitude é uma reação aprendida resultante de observações anteriores, de experiências diretas ou da exposição às atitudes dos outros. O grupo Atitude Ambiental (AA) soma nove variáveis que tem como objetivo conhecer as atitudes tomadas pelos moradores quanto às seguintes variáveis: At_ag (consumo de água); At_eg (consumo de energia); At_ef (destino de efluentes); At_cs (coleta seletiva de resíduos sólidos); At_rs (redução de resíduos sólidos); At_oc (descarte do óleo de cozinha); At_av (manutenção de área verde - jardinagem)); At_se (uso de sacolas ecológicas) e At_pe (utilização de produtos ecologicamente corretos). Cada variável apresentada acompanhou um espaço para o respondente especificar as atitudes ambientais relacionadas.

O grupo Gestão Ambiental (GA) pretende analisar a necessidade que os moradores percebem em implementar programas ambientais no condomínio, além de avaliar o grau de disponibilidade de custo financeiro aliada à consciência ambiental. Esse grupo possui grande importância já que tem como objetivo perceber a possível aplicação de um Sistema de Gestão Ambiental (SGA). O grupo GA possui nove variáveis relacionadas à necessidade dos seguintes programas de gestão ambiental: Nec_ac (reaproveitamento de água de chuva); Nec_ap (reaproveitamento de água da piscina); Nec_ca (redução do consumo de água); Nec_ce (redução do consumo de energia); Nec_ea (consumo de energia alternativa); Nec_pe (Necessidade da implementação de programas voltados para plantio de espécies); Nec_ple (consumo de produtos de limpeza ecologicamente corretos); Nec_pea (palestras de educação ambiental) e Nec_cc (Opinião do respondente sobre a implementação dos programas caso representem aumento mensal no custo do condomínio).

Em um primeiro momento foi feito um pré-teste do questionário piloto aplicado com dois moradores. Em seguida, foram efetuadas algumas modificações, no intuito de aprimorar o questionário com perguntas mais claras e objetivas. A aplicação dos questionários foi realizada na primeira quinzena do mês de setembro de 2009.

\subsection{Técnica de análise de dados}

Após recolhimento dos questionários os dados foram tabulados e analisados por técnicas estatísticas descritivas e por análise de agrupamento (Cluster). O objetivo principal em se utilizar a análise descritiva dos valores absolutos e dos percentuais obtidos é o de apresentar a percepção dos respondentes sobre os fatores direcionadores das variáveis, abordando na forma de tabelas e gráficos baseados em dados da amostra coletada, considerando os resultados das variáveis (Carvalho \& Silva, 2009).

A análise de cluster tem como objetivo correlacionar as diversas variáveis dos grupos pertinentes ao estudo, sendo apresentado os resultados em gráficos e tabelas. Para isto, utilizou-se o software específico de estatística "Statistic 6.0".

\section{RESULTADOS E DISCUSSÃO}

\subsection{Validação da Pesquisa}

A amostra inicial da pesquisa corresponde a um universo de 43 residências, estando 38 habitadas e 05 disponíveis para venda ou aluguel. A amostra aplicada foi de 38 questionários com uma taxa de retorno de reposta de $76 \%$ ou seja, 29 respondidos. Foi estabelecido contato com todas as residências, no entanto por motivos individuais de alguns condôminos não foi possível obter o retorno das respostas em sua totalidade.

\subsection{Análise Descritiva}

\subsubsection{Perfil dos respondentes}

(C) RGSA - v.4, n.1, jan./abr. 2010

www.gestaosocioambiental.net 
Entre os respondentes, predomina o sexo feminino (64\%), pessoas com idade inferior a 50 anos $(72 \%)$, casados $(77 \%)$, moram em média entre 3 a 5 pessoas por casa $(60 \%)$. Em mais da metade das casas do condomínio (52\%) moram crianças (Figura 2).

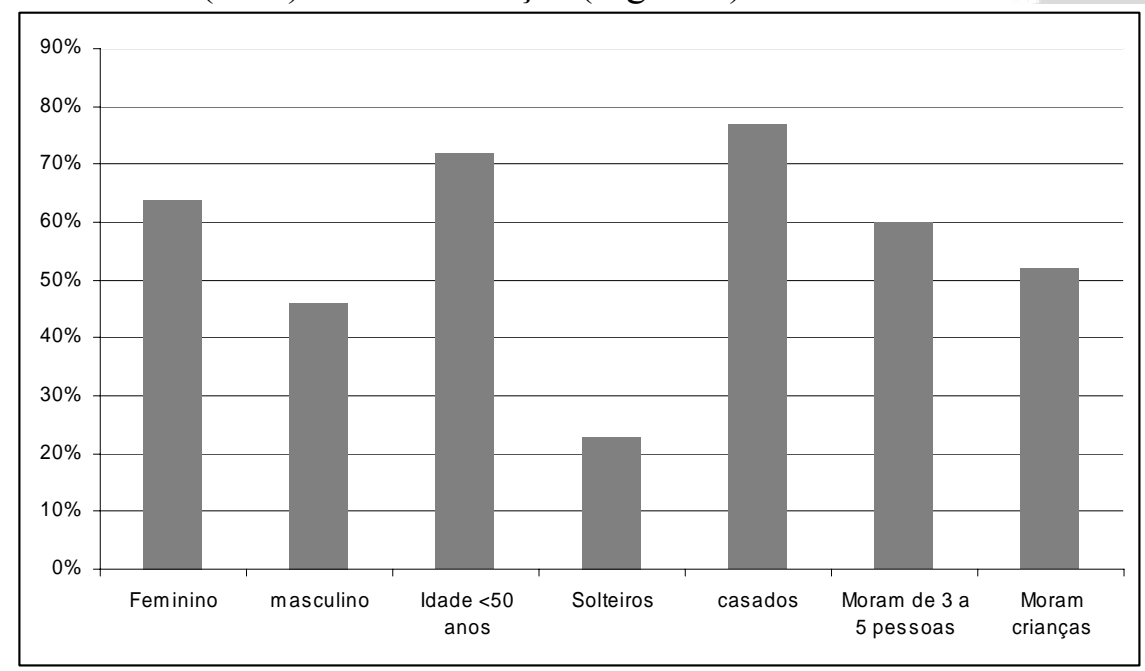

Figura 2 - Perfil dos respondentes

Quanto ao grau de instrução, tem-se uma prevalência do nível superior e pós graduação (73\%), seguido do médio e técnico com $24 \%$. Não houve entrevistados do nível fundamental ou médio incompleto.

Ainda em relação ao sexo, a predominância do sexo feminino pode ser justificada pelo fato que os chefes de família designaram a tarefa de preencher o questionário às mulheres, essa atitude infere que há no condomínio uma mentalidade de que o cuidado ambiental está mais relacionado ao sexo feminino, embora podem existir diversos fatores que influenciaram este fato, talvez mais predominante do que a questão ambiental.

\subsubsection{Consciência Ambiental (CA)}

As variáveis relativas ao grupo CA apresentam dados estatísticos que evidenciam que existe uma consciência ambiental elevada na média geral. No entanto, algumas das variáveis, como Op_ce e Op_ap denotam uma menor consciência quanto aos efluentes (Op_ce) e águas pluviais Op_ap).

Tabela 2 - Descrição estatística do grupo Consciência Ambiental

\begin{tabular}{|c|c|c|c|c|c|}
\hline Variáveis & $\begin{array}{c}\text { Média - } \\
\text { Me }\end{array}$ & Mediana & Variância & $\begin{array}{c}\text { Desvio padrão - } \\
\text { DP }\end{array}$ & $\begin{array}{c}\text { CoeficienteVariação - } \\
\text { CV }\end{array}$ \\
\hline Op_imp & 3,51 & 4 & 1,76 & 1,35 & 38,46 \\
\hline Op_ca & 3,06 & 4 & 3,30 & 1,85 & 60,46 \\
\hline Op_ce & 3,0 & 4 & 2,51 & 1,62 & 54,00 \\
\hline Op_ef & 4,24 & 5 & 1,70 & 1,32 & 31,13 \\
\hline Op_gr & 3,75 & 5 & 2,66 & 1,66 & 44,27 \\
\hline Op_av & 3,06 & 4 & 3,37 & 1,87 & 61,11 \\
\hline Op_ap & 2,82 & 4 & 3,38 & 1,87 & 66,31 \\
\hline Op_oc & 4,27 & 5 & 1,78 & 1,36 & 31,85 \\
\hline Imp_amb & 4,96 & 5 & 0,03 & 0,18 & 3,63 \\
\hline
\end{tabular}

Pode-se observar, a partir da Tabela 2, que a variável Op_ap possui uma grande variação, de $66,31 \%$, o que implica que a média tem uma pequena representatividade; ela representa apenas

(C) RGSA - v.4, n.1, jan./abr. 2010

www.gestaosocioambiental.net 
$33,69 \%$ dos dados. O que quer dizer que somente essa porcentagem acredita que o manejo das águas pluviais possa gerar problemas ambientais para o condomínio. Porém, a variável Imp_amb apresenta uma variação muito baixa, 3,63\%, evidenciando que ela tem uma grande representatividade: na realidade ela representa $96,37 \%$ dos dados, ou seja de entrevistados que acreditam que é importante o cuidado com o meio ambiente dentro do condomínio.

Dentro das questões do grupo CA questionou-se a possibilidade do condomínio causar danos ambientais. A maioria dos entrevistados concorda totalmente ou em parte $(68,9 \%)$ que o condomínio possa gerar danos para o meio ambiente, enquanto $31 \%$ discordam totalmente ou em parte (Figura 2). Esse número reflete uma relativa desinformação quanto ao termo dano ambiental, já que qualquer empreendimento possui um potencial poluidor em diferentes escalas.

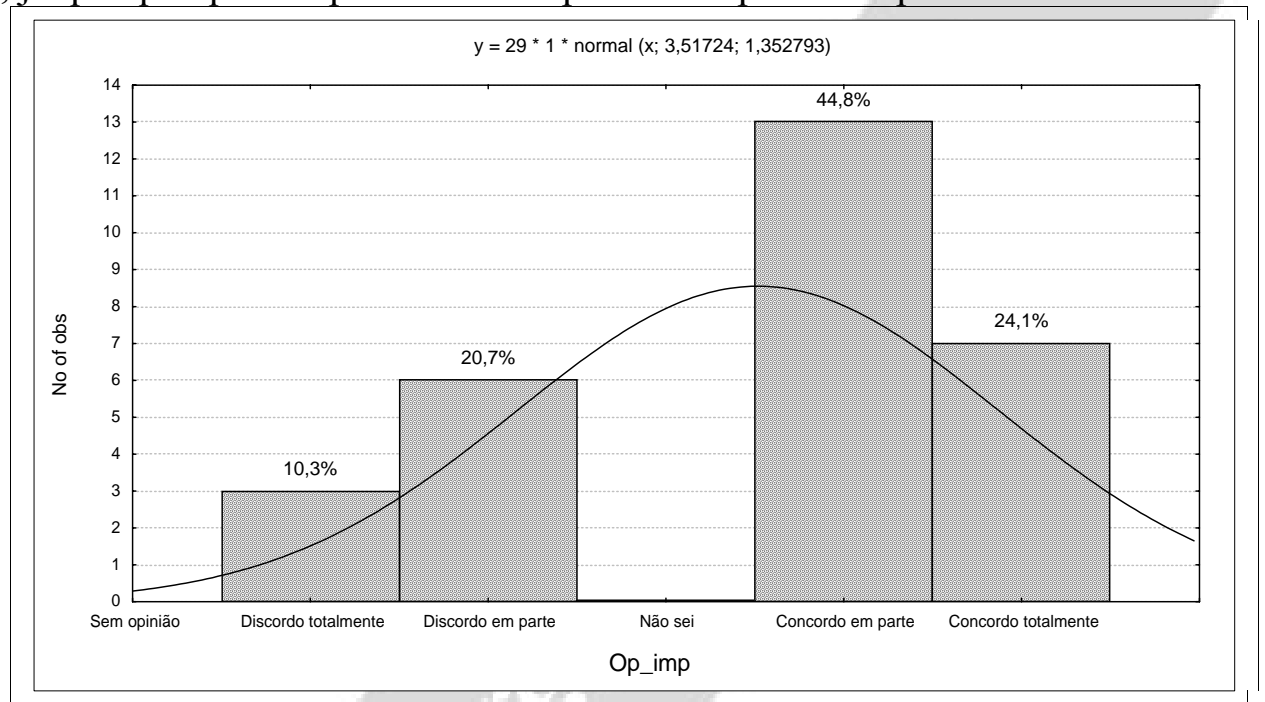

Figura 3 - Opinião dos entrevistados sobre danos ambientais no condomínio

Apesar de $73 \%$ dos entrevistados apresentarem grau de instrução concentrado entre superior e pós-graduação, é possível perceber que o nível de consciência ambiental muitas vezes não está de acordo com a formação educacional. Destaca-se que 96,5\% acreditam que é importante haver o cuidado ambiental dentro do condomínio. O que gera uma contradição, pois apesar de muitos acharem que o condomínio não causa danos ambientais, pensam que é importante ter cuidados ambiental. Pelas respostas, nota-se que uma parcela da amostra, considera que o condomínio esteja imune de causar problemas ambientais, embora é preciso manter um certo cuidado.

\subsubsection{Atitude Ambiental (AA)}

O grupo Atitude Ambiental apresentou uma média das variáveis relativamente menor comparando com o grupo CA. As variáveis sobre a disposição de óleo de cozinha (at_oc) e o uso de sacolas ecológicas (at_se) denotam um nível baixo quanto ao que se espera de boas práticas ambientais, conforme observa-se na Tabela 3.

Tabela 3 - Descrição estatística do grupo Atitude Ambiental

\begin{tabular}{|c|c|c|c|c|c|}
\hline Variáveis & Média & Mediana & Variância & $\begin{array}{c}\text { Desvio } \\
\text { padrão }\end{array}$ & $\begin{array}{c}\text { CoeficienteVariação } \\
\mathbf{- C V}\end{array}$ \\
\hline At_ag & 4,65 & 5 & 0,22 & 0,48 & 10,32 \\
\hline At_eg & 4,44 & 5 & 1,07 & 1,05 & 23,65 \\
\hline At_ef & 3,14 & 4 & 1,63 & 1,30 & 41,40 \\
\hline At_cs & 3,48 & 4 & 1,49 & 1,24 & 35,63 \\
\hline
\end{tabular}




\begin{tabular}{|l|l|l|l|l|l|}
\hline At_rs & 3,45 & 4 & 2,25 & 1,52 & 44,06 \\
\hline At_oc & 2,24 & 2 & 3,01 & 1,76 & 78,57 \\
\hline At_av & 4,31 & 4 & 0,42 & 0,66 & 15,31 \\
\hline At_se & 2,24 & 2 & 0,73 & 0,87 & 38,83 \\
\hline At_pe & 3,48 & 4 & 1,42 & 1,21 & 34,77 \\
\hline
\end{tabular}

A variável at_av representa o cuidado que os moradores têm com a manutenção de seus jardins. A maioria das residências não possui árvores frutíferas e de grande porte, predominando o aspecto de paisagismo. A maioria (54\%) prefere contratar um profissional paisagístico para manter sua área verde sempre bem cuidada. A variável que trata do consumo de água (At_ag) foi a que melhor se aproximou da média máxima, o que reflete corretas atitudes voltadas para a prática racional deste recurso natural.

As sacolas ecológicas (At_se) ainda são pouco usuais entre os condôminos. 79,3\% não utilizam, mas afirmam que podem vir a usar. Somente $3,4 \%$ afirmam ter sempre a mão e sempre utilizam. Enquanto $6,9 \%$ não utilizam as sacolas por achar ineficientes, conforme constata-se, na figura a seguir:

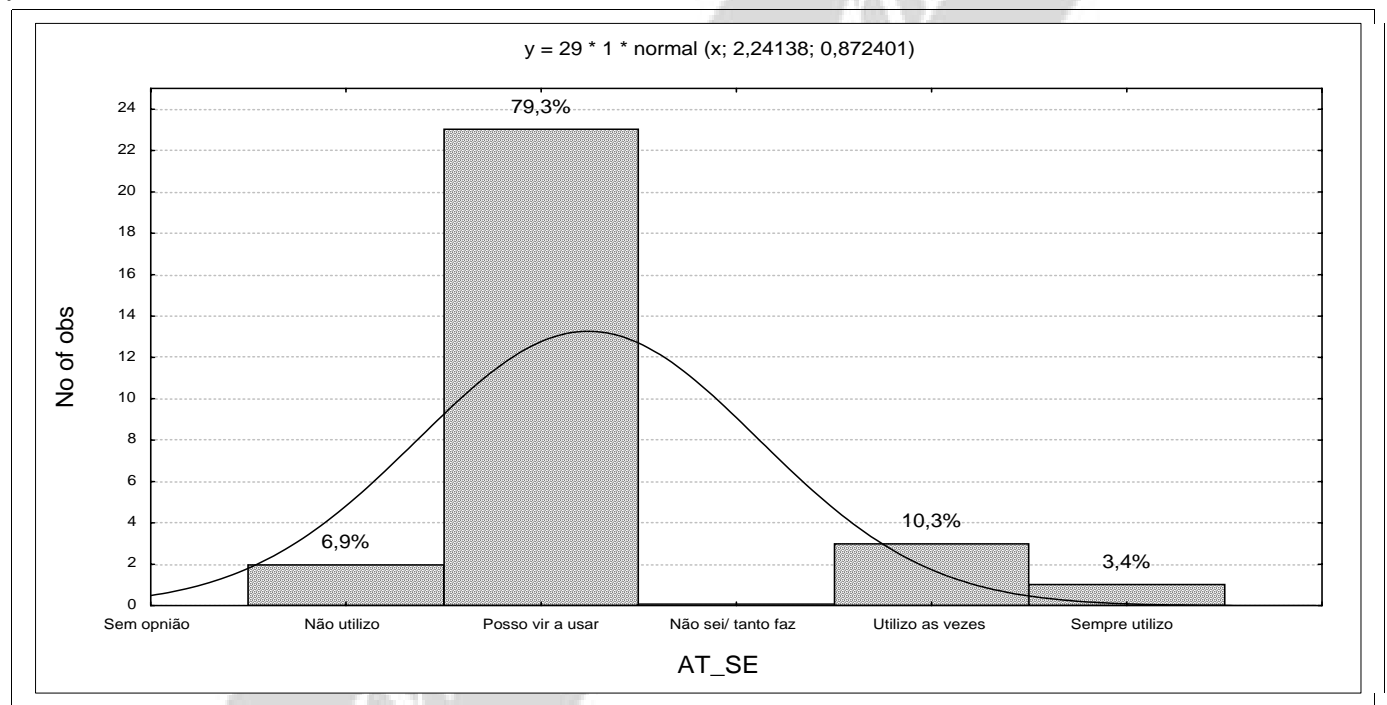

Figura 4 - Atitude sobre o uso de sacolas ecológicas

Um exemplo dado por uma moradora é que sua feira não caberia em uma ou duas sacolas ecológicas, assim acredita que são ineficientes e prefere usar o saco plástico que é reutilizado para acondicionar os resíduos sólidos gerado em sua residência.

A compra de produtos ecologicamente corretos (At_pe) está diretamente relacionada ao custo. Do total, $55,2 \%$ só compra se estiver em promoção e $24,1 \%$ já tem em mente que custam caros, e por isso não utilizam (Figura 5). Alguns moradores gostariam de ter mais informações sobre o que são e quais são os produtos ecologicamente corretos, enquanto outros afirmam que há uma dificuldade local em encontrar nas prateleiras tais produtos. 


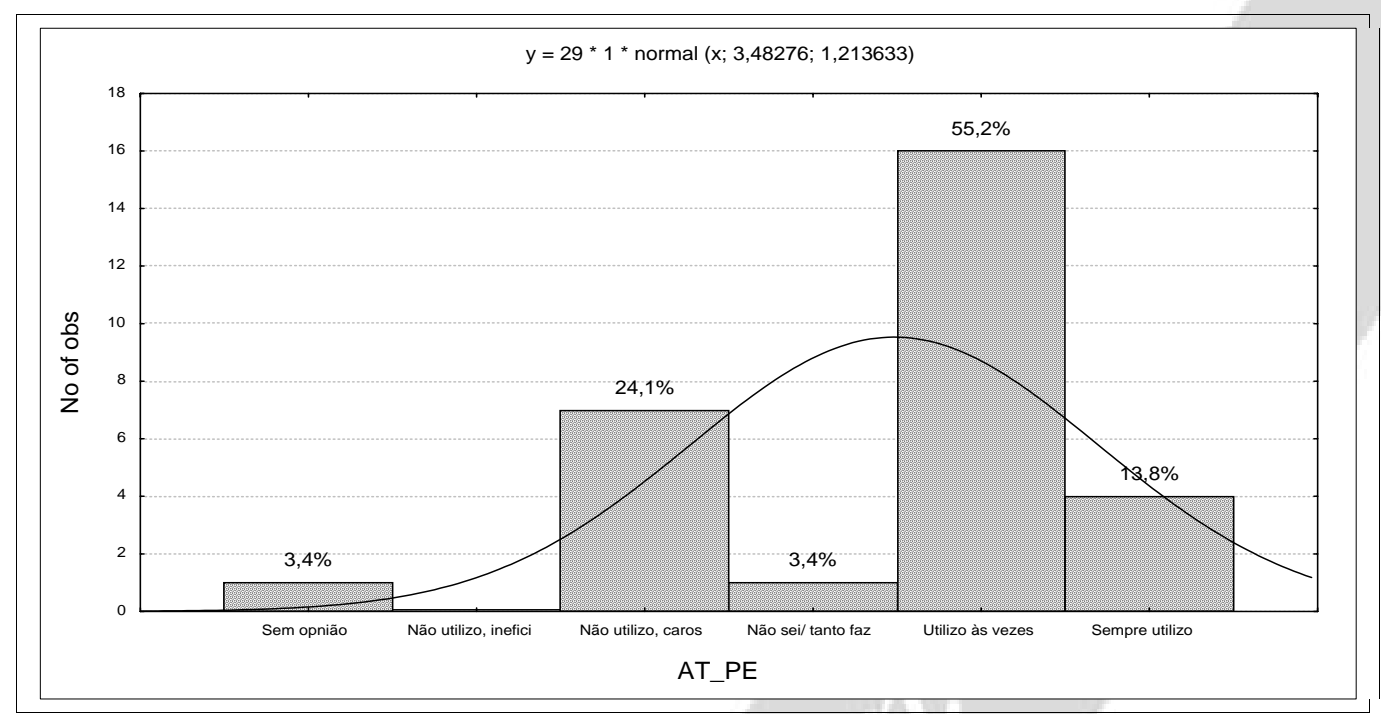

Figura 5 - Atitude sobre a utilização de produtos ecologicamente correto

\subsubsection{Gestão Ambiental (GA)}

Este grupo apresentou uma maior consonância entre as respostas. As variáveis apresentaram valores esperados pela média (5). A menor média apresentada $(3,76)$ diz respeito à variável que avalia a implementação de programas ambientais caso represente custo financeiro para os condôminos, conforme observa-se a seguir:

Tabela 4 - Descrição estatística do grupo Gestão Ambiental

\begin{tabular}{|c|c|c|c|c|c|}
\hline Variáveis & Média & Mediana & Variância & $\begin{array}{c}\text { Desvio } \\
\text { padrão }\end{array}$ & $\begin{array}{c}\text { CoeficienteVariação } \\
\text { - CV }\end{array}$ \\
\hline Nec_ac & 4,89 & 5 & 0,09 & 0,31 & 6,33 \\
\hline Nec_ap & 4,75 & 5 & 0,59 & 0,79 & 16,63 \\
\hline Nec_ca & 4,65 & 5 & 0,63 & 0,81 & 17,41 \\
\hline Nec_ce & 4,79 & 5 & 0,16 & 0,41 & 8,55 \\
\hline Nec_ea & 4,68 & 5 & 0,90 & 0,97 & 20,72 \\
\hline Nec_pe & 4,82 & 5 & 0,83 & 0,93 & 19,29 \\
\hline Nec_ple & 4,86 & 5 & 0,11 & 0,35 & 7,20 \\
\hline Nec_pea & 4,96 & 5 & 0,03 & 0,18 & 3,63 \\
\hline Nec_cc & 3,76 & 4 & 1,35 & 1,18 & 31,38 \\
\hline
\end{tabular}

A grande maioria dos entrevistados $(72,4 \%)$ se mostrou favorável à implementação de um programa voltado para o reaproveitamento da água de chuva e da piscina, enquanto $27,6 \%$ concorda em parte com a medida. Para os programas de redução do consumo de água e energia, $81 \%$ acredita ser necessário incentivar a prática no condomínio. Para o uso de energias alternativas, $81 \%$ se mostrou favorável ao uso no condomínio.

Sobre a necessidade da implementação de programas voltados para o plantio de espécies, $86 \%$ apresenta uma postura positiva, o que representa impulso quanto à implementação de um programa de arborização. A quantidade de espécies nativas são poucas tanto nos espaços de áreas comuns, quanto nas privadas. 
Destaca-se ainda que a totalidade dos moradores é a favor da implementação de programas voltados para consumo de produtos de limpeza ecologicamente corretos e que $92 \%$ gostariam de participar de palestras de educação ambiental voltadas para os temas tratados no questionário.

Assim, observa-se um interesse representativo pela inserção de programas de gestão ambiental pelos condomínios. Porém, quando estes programas estão relacionados a um aumento dos custos mensal, nota-se, considerando a Figura 6 , uma preocupação significativa com o custo financeiro em detrimento do custo ambiental, já que $27,6 \%$ da mostra tem o interesse pelos programas desde que sem custo adicional e 41,4\% pelos programas com o menor custo. Ou seja, percebe-se que o interesse da aplicação dos programas ambientais não é o mesmo quando estes representassem um aumento do valor mensal pago de condomínio. Isto pode ser associado ao fato que o modelo capitalista ainda está longe de atingir uma sustentabilidade ambiental.

No espaço reservado para sugestões, comentários e críticas, considerou-se a importância de incluir um programa de educação ambiental voltado para a prática proibida da criação de animais silvestres em cativeiro nas casas, assim como o consumo comum e cultural de animais caçados, como avoantes e tatu. Ainda, alguns condôminos recomendaram uma avaliação dos programas e atribuição de prioridades com relação às metas de projetos a serem implementados.

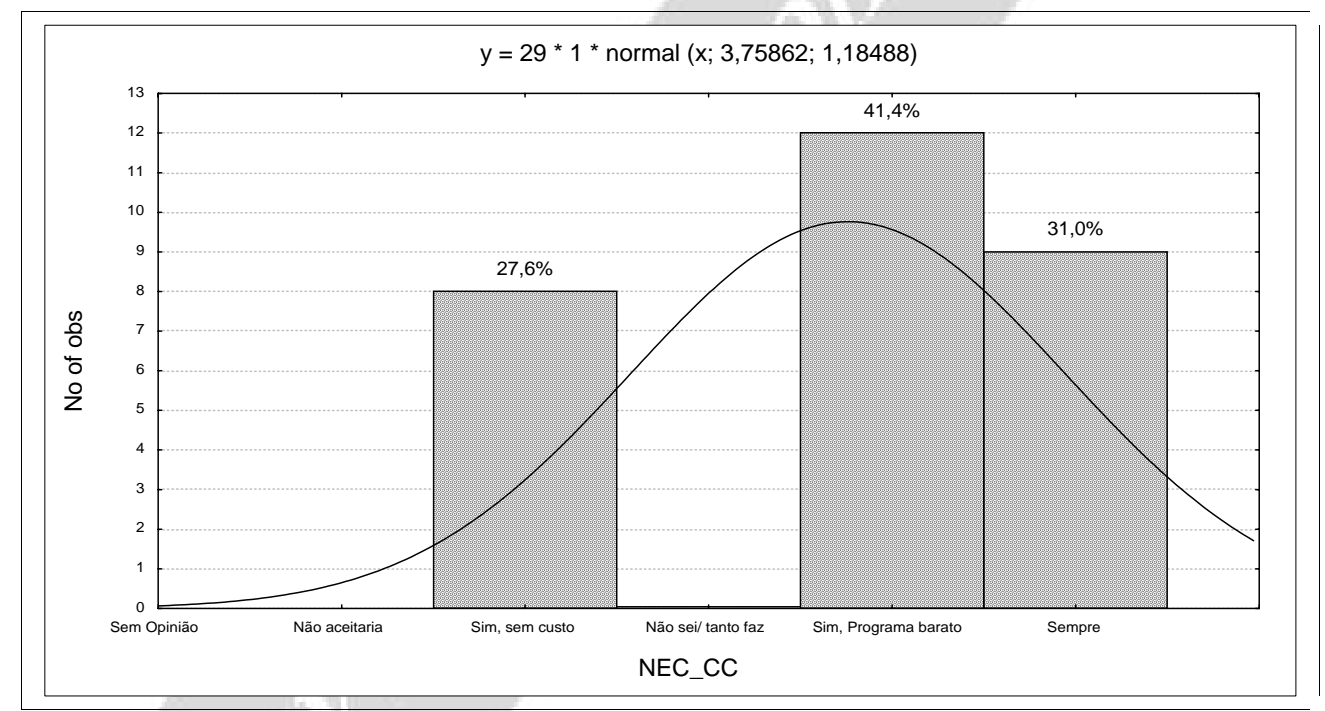

Figura 6 - Necessidade de implementação de programas ambientais

\subsubsection{Relação entre grupos: consciência $x$ atitude}

Os gráficos relacionando os grupos CA e AA apresentam no eixo das categorias uma numeração ( 0 a 5) referente às respostas sobre consciência (Ver descrição na tabela 1, na metodologia), assim como ao lado apresentam as opções descritivas relativas à atitude ambiental. Destaca-se que neste tópico foram escolhidas, as variáveis relacionadas ao consumo de água, energia, geração de efluentes e resíduos, por se tratarem de aspectos ambientais significativos em um condomínio.

\section{A) Água}

Sobre o consumo de água, 58,62\% acreditam que o consumo de água pode gerar problemas ambientais no condomínio. Desses, $31,03 \%$ concordam em parte, ou seja, o consumo de água pode não gerar problemas. Grande parcela dos condôminos não vê problemas com o consumo de água (Consciência Ambiental - Variável Op_ca) . 
Quanto às atitudes ambientais relacionada ao consumo de água, 73\% dos condôminos afirmaram economizar sempre água em sua residência e que se preocupam não só com o custo da conta, mas também com o volume utilizado no mês. O restante dos entrevistados, $27 \%$, disseram se preocupar, mas não ser radical a ponto de pensar sempre na economia. As respostas se concentraram na preocupação com a economia desse bem.

Comparando a consciência acerca do consumo de água no condomínio e a atitude acerca da redução do consumo de água, nota-se que quanto à consciência, a maior parcela $(31,03 \%)$ concorda "em parte" que o consumo de água possa gerar prejuízos ambientais para o condomínio, embora, $37,93 \%$ se preocupam com o volume e valor gasto com água (Figura 7).

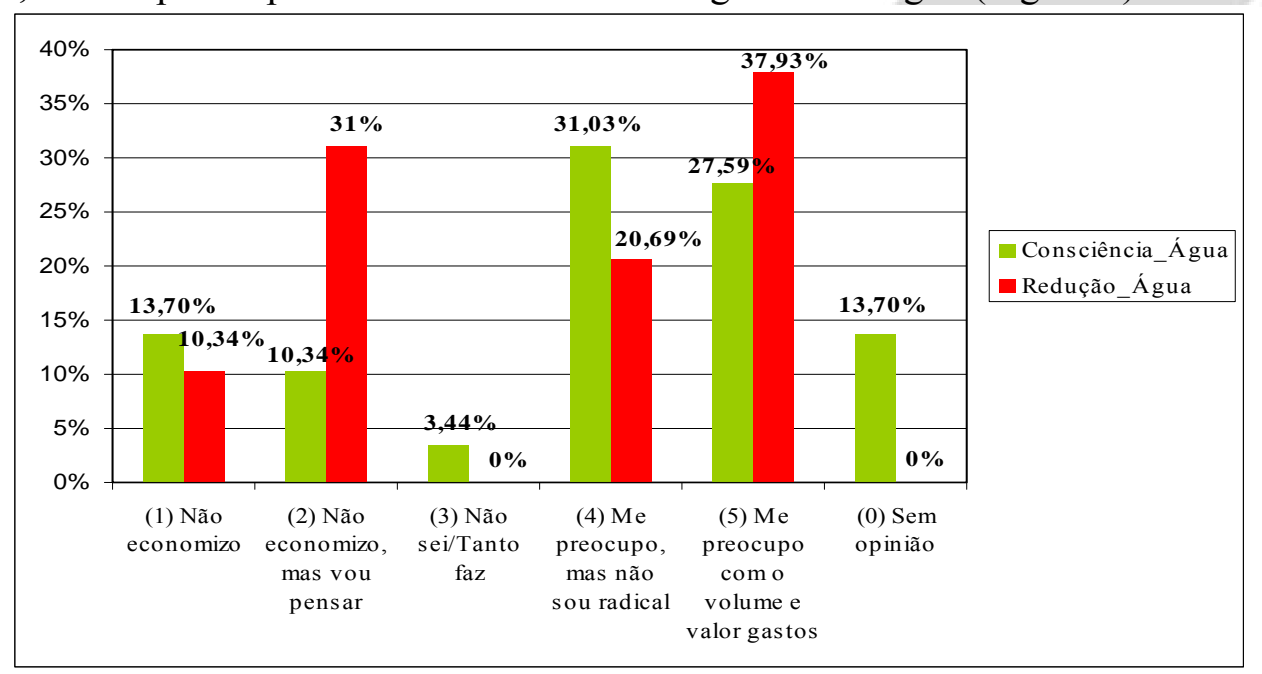

Figura 7 - Relação entre a consciência e atitudes sobre o consumo de água.

Onde, para barras verdes, (1) - Sem opinião, (2) - Discordo totalmente, (3) - Discordo em parte, (4) - Concordo em parte, (5) - Concordo totalmente e (0) Sem opinião (Tabela 1). * (O consumo de água pode representar um problema ambiental de um condomínio?) (Variável Op_ca)

Usando uma matriz de correlação entre estas variáveis, o coeficiente de correlação (r) calculado (OP_CA vs. AT_AG) foi de 0,227. Mesmo sendo positivo, o que demonstra uma certa relação, observa-se um valor relativamente baixo. Com isso, percebe-se que não necessariamente as pessoas com maior consciência são as que têm as melhores práticas e vice-versa.

No espaço destinado às especificações das atitudes voltadas para redução do consumo de água, alguns dos moradores citaram ações como otimizar o tempo durante o banho; reduzir descargas, urinando durante o banho; fechar a torneira enquanto ensaboa no banho ou escova os dentes; lavar a louça com a torneira controlada; juntar roupas até a capacidade máxima da máquina de lavar roupas; aproveitar a água de molho das roupas para lavar, por exemplo, a banheira das crianças; evitar regar o jardim em demasia; evitar vazamentos; educar as pessoas de casa. Algumas casas já possuem cisternas para aproveitamento de água pluviais que podem ser usadas na limpeza de casa ou para a rega do jardim.

\section{B) Energia}

Com relação ao consumo de energia, 44,83\% concordam em parte que o consumo de energia pode acarretar problemas ambientais para o condomínio (Consciência Ambiental - Variável Op_ce). No entanto, $72,41 \%$ dos condôminos afirmaram economizar sempre energia em sua 
residência e que se preocupam não só com o custo da conta, mas também com a potência consumida no mês. O restante dos entrevistados, 13,79\%, disseram economizar somente por ser rigoroso com o valor da conta no final do mês. E outros $14 \%$ afirma não economizar, mas que vai pensar nessa prática.

A figura 8 mostra uma comparação entre a consciência e atitude dos condôminos acerca do consumo de energia no condomínio. Apesar de haver uma minoria $(13,79 \%)$ entre os que concordam totalmente com a possibilidade do gasto de energia poder causar problemas ambientais, a grande maioria $(72,41 \%)$ se preocupa em economizar energia em suas casas.

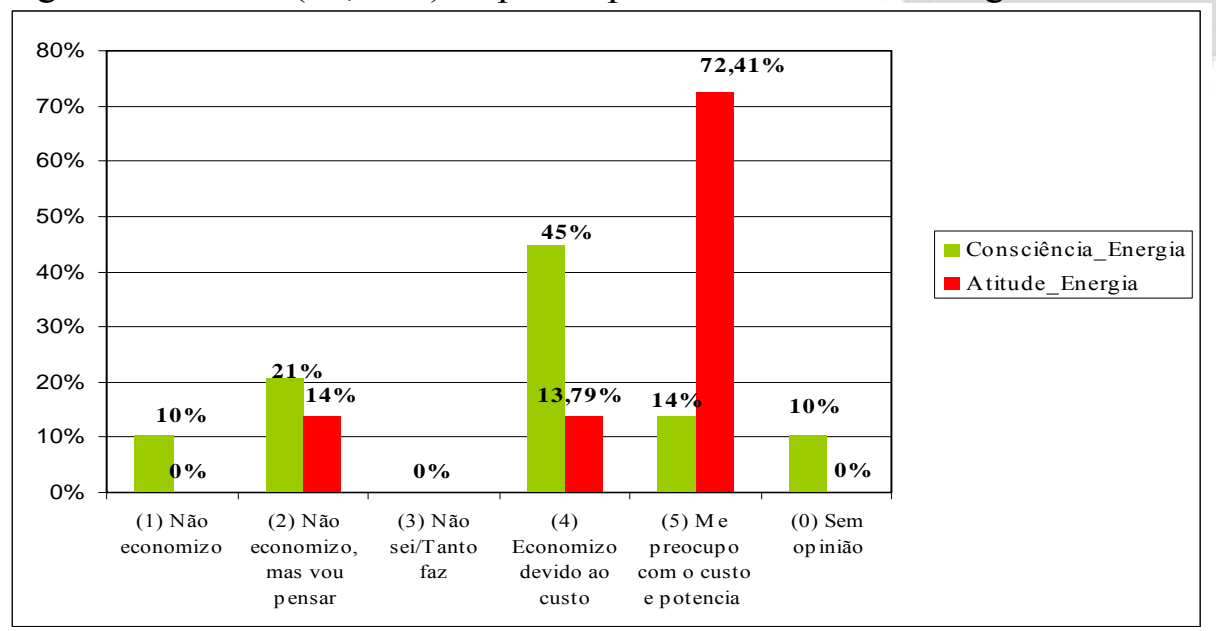

Figura 8 - Relação entre a consciência e atitudes sobre o consumo de energia

Onde, para barras verdes, (1) - Sem opinião, (2) - Discordo totalmente, (3) - Discordo em parte, (4) - Concordo em parte, (5) - Concordo totalmente e (0) Sem opinião (Tabela 1). * (O consumo de energia pode representar um problema ambiental de um condomínio?) (Variável Op_ce)

Usando uma matriz de correlação entre a consciência e a atitude relacionada ao consumo energético, o coeficiente de correlação (r) calculado (OP_CE vs. AT_EG) foi de “- 0,17”. Pelo resultado, nota-se que não há uma correlação entre estas variáveis, ou seja, mesmo tendo uma atitude positiva, certamente por questões financeiras, a conscientização de que o consumo energético consiste em um aspecto ambiental significativo em um condomínio não é considerada. No espaço destinado às especificações das atitudes voltadas para redução do consumo de energia, alguns dos moradores citaram ações como utilizar lâmpadas fluorescentes; trocar eletrodomésticos que consomem mais energia pelos mais econômicos; só deixar lâmpadas e aparelhos ligados onde existe alguém usando; não engomar roupa de cama, mesa e banho; engomar somente muitas peças de uma vez só; evitar banhos de chuveiro elétrico; evitar o uso de microondas e fogão elétrico; evitar o uso de ar condicionado.

\section{C) Efluentes}

Em relação à atitude ambiental frente a geração dos efluentes líquidos, a maioria dos entrevistados $(37,93 \%)$, responderam que tem conhecimento básico sobre o destino do esgoto do condomínio, enquanto $31 \%$ não sabem para onde vai, mas gostaria de ser informado(a). Grande parcela dos entrevistados gostaria de ter conhecimento sobre o destino dos efluentes, dessa forma subtende-se iriam saber na prática como promover a redução de esgoto. 
Pela figura 9 , ressalta-se que $65,52 \%$ têm consciência de que a disposição incorreta de efluente causa problemas ambientais (Consciência Ambiental - Variável Op_ef). No entanto, somente $13,79 \%$ têm conhecimento sobre o destino final do esgoto do condomínio e colabora com a redução do volume de esgoto gerado (Atitude Ambiental - Variavel At_ef).

Usando uma matriz de correlação entre a consciência e a atitude relacionada aos efluentes sanitários, o coeficiente de correlação (r) calculado (OP_EF vs. AT_EF) foi de 0,08. Pelo resultado, nota-se uma correlação praticamente nula.

No espaço destinado às especificações das atitudes voltadas para o destino dos efluentes, alguns moradores estão cientes de que o esgoto segue para fossa séptica individual de cada casa, comprometendo o lençol freático. Como alternativa viável apontam as redes municipais de coleta e tratamento, que ainda não está sendo realizada no bairro. Alguns moradores dizem reutilizar os efluentes de máquina de lavar roupas e da piscina para irrigação do jardim.

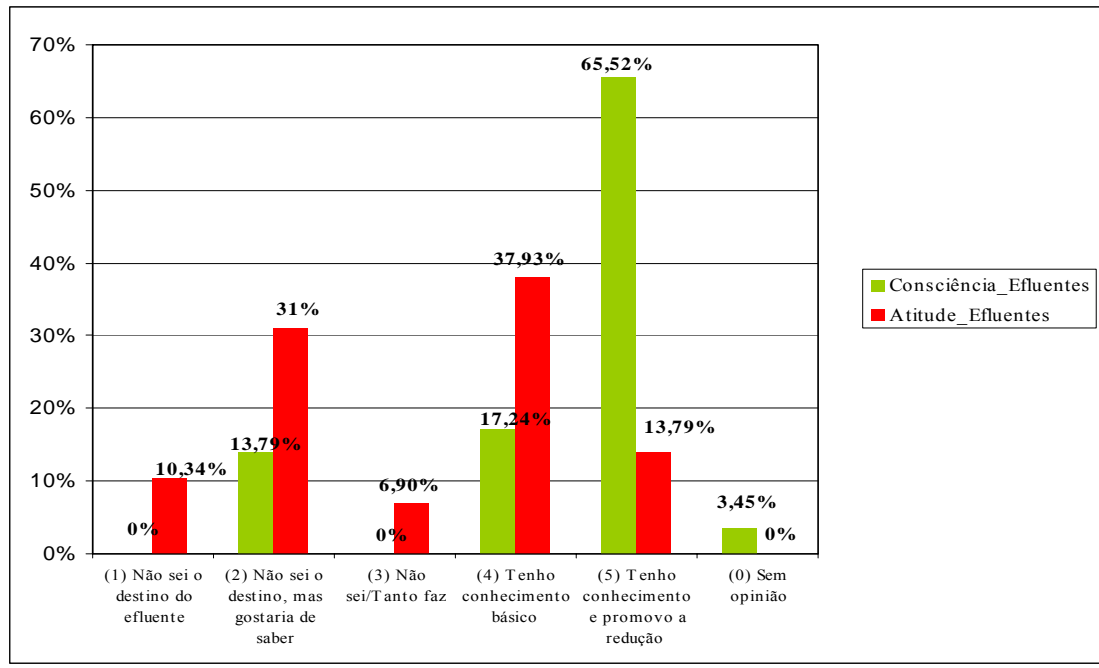

Figura 9 - Relação entre a consciência e atitudes do destino de efluentes

Onde, para barras verdes, (1) - Sem opinião, (2) - Discordo totalmente, (3) - Discordo em parte, (4) - Concordo em parte, (5) - Concordo totalmente e (0) Sem opinião (Tabela 1).

* (A geração de efluente pode representar um problema ambiental de um condomínio?) (Variável Op_ef)

\section{D) Resíduos Sólidos}

O resultado mostra que $51,72 \%$ dos condôminos acreditam totalmente que a geração de resíduos sólidos e um condomínio pode gerar problemas ambientais (Consciência Ambiental - Variavel Op_gr).

Em relação à atitude, parte dos entrevistados (37,93\%) assegura fazer a separação dos resíduos. Grande parte $(31,03 \%)$ não faz idéia para onde vai o resíduo sólido gerado em sua casa, mas gostaria de saber (Atitude Ambiental - Variável - At_cs - separação dos resíduos).

A maioria dos entrevistados (37,93\%) se compromete em reduzir o consumo de resíduos, comprando o que lhes parece ser útil. Uma grande parcela $(31,03 \%)$ não sabe o que fazer para reduzir a quantidade de resíduos gerada em suas casas, mas gostaria de saber como (Atitude Ambiental - Variável - At_rs - redução dos resíduos). 
Na figura 10, observa-se o alto índice $(51,72 \%)$ de consciência sobre os problemas ambientais gerados a partir do mau gerenciamento dos resíduos sólidos. No entanto, a prática de redução ainda tem pouca representatividade (37,93\%) (Variável - At_rs).

Destaca-se também, que usando uma matriz de correlação, o coeficiente de correlação (r) calculado (OP_GR vs. AT_RS) foi de “- 0,01 ”, o que demonstra nenhuma relação entre a consciência e a atitude relacionada com os resíduos.

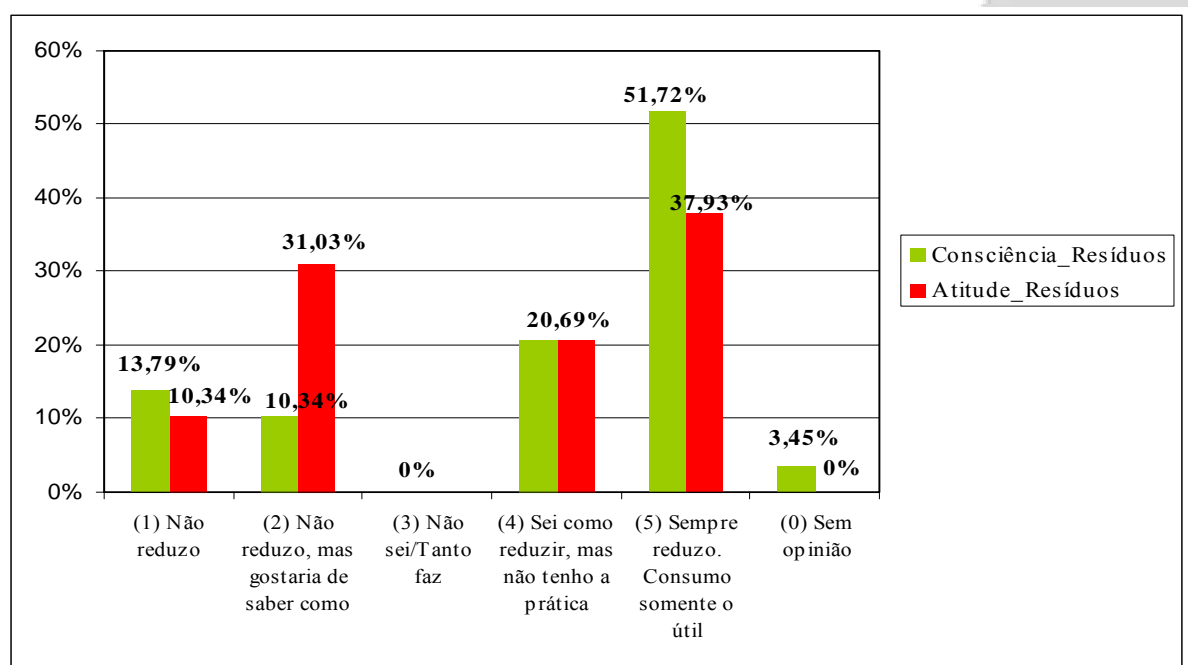

Figura 10 - Relação entre a consciência e atitudes sobre a geração de resíduos sólidos

Onde, para barras verdes, (1) - Sem opinião, (2) - Discordo totalmente, (3) - Discordo em parte, (4) - Concordo em parte, (5) - Concordo totalmente e (0) Sem opinião (Tabela 1).

* (A geração de resíduos sólidos pode representar um problema ambiental de um condomínio?)

(Variável Op_gr)

Algumas ações foram listadas como práticas utilizadas para redução da geração de resíduos, como a produção de alimentos controlada de modo a não gerar desperdício; reutilização de sacolas, potes plásticos e vidros de embalagens; ao comprar produtos em padaria ou supermercado preferir sacolas de papel; compra de produtos que utilizem embalagens do tipo refil; verifica se a embalagem possui o selo de reciclagem.

Considerando o óleo de cozinha, um resíduo sólido devido a sua alta carga poluidora, o que não recomenda seu lançamento em um sistema de esgotamento sanitário, foi observado que a maioria dos respondentes, ainda efetua o lançamento no ralo da pia como alternativa de descarte $(47,79 \%)$. No entanto, muitos (34\%) gostariam de ser informados se existe uma forma correta de descarte. A opção correta para descarte, em garrafas pet para reciclagem, também mostrou uma porcentagem considerável (17,24\%). Destaque para a porcentagem $(21 \%)$ de entrevistados que não tem opinião sobre o assunto (Atitude Ambiental - Variável - At_oc).

A figura 10 mostra que existe um alto nível de consciência $(69 \%)$ acerca dos problemas que podem ser gerados a partir do descarte de óleo de cozinha usado na pia (Consciência Ambiental Variável - Op_oc), no entanto, somente 17,24\% descartam o óleo da forma correta. 


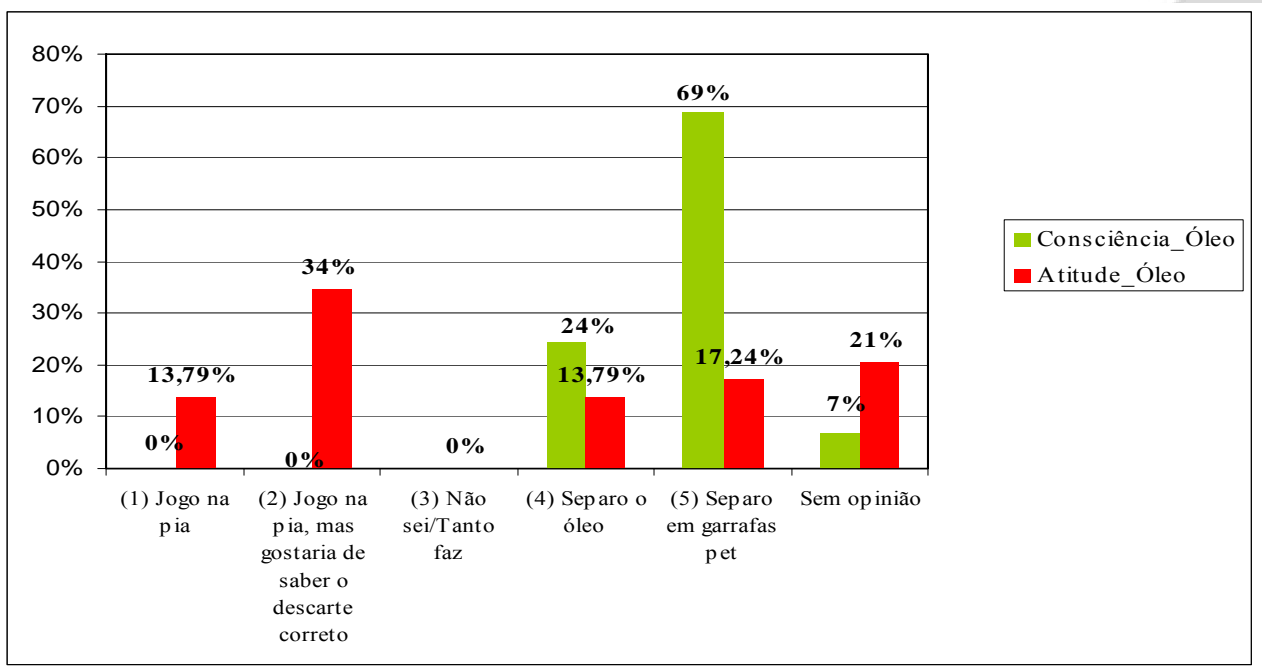

Figura 11 - Relação entre a consciência e atitudes do descarte de óleo de cozinha usado

Onde, para barras verdes, (1) - Sem opinião, (2) - Discordo totalmente, (3) - Discordo em parte, (4) - Concordo em parte, (5) - Concordo totalmente e (0) Sem opinião (Tabela 1).

* (A destinação do óleo de cozinha pode representar um problema ambiental de um condomínio?) (Variável Op_oc)

No espaço destinado às especificações das atitudes voltadas para o destino do óleo de cozinha, $9 \%$ dos moradores informaram que não utilizam óleo para frituras na alimentação.

\subsection{Análise de Cluster}

Com embasamento na análise descritiva, partiu-se para a análise através de técnicas de estatísticas multivariadas, objetivando a determinação de grupos homogêneos em relação às respostas atribuídas pelos condôminos. Destaca-se que a análise de cluster consiste em uma técnica para classificar dados ou variáveis em grupos ou classes (Becker, 1994 \& Kvanli, Guynes, Pavur, 1996).

Foram estudadas as 27 variáveis do questionário que compõem os três grupos (CA, AA e GA) estudados nessa nesta analise (todas com a mesma escala), sendo utilizado como critério de significância para composição dos agrupamentos o nível de probabilidade $\mathrm{p} \leq 0,05$.

Os resultados da análise inicial encontram-se na tabela 5. Pelos resultados, observa-se que existe heterogeneidade significativa entre dois dos três conglomerados, principalmente nas variáveis relacionadas à atitude e a necessidade ambiental. Assim, considerando o critério de significância $\mathrm{p} \leq 0,05$, as variáveis OP_CA, OP_CE, OP_EF, OP_GR, OP_AV, OP_AP, AT_CS e NEC_CE formaram dois grupos de clusters selecionados. 
Tabela 5 - Análise de variância para formação de agrupamentos enfocando 27 variáveis relacionadas

\begin{tabular}{|c|c|c|c|c|c|c|}
\hline Variáveis & Entre SS & df & Dentro SS & Df & F & p-valor \\
\hline OP_IMP & 5,379475 & 1 & 45,8619 & 27 & 3,167025 & 0,08639905 \\
\hline OP_CA & 66,62874 & 1 & 29,23333 & 27 & 61,53852 & 0,00000002 \\
\hline OP_CE & 49,85238 & 1 & 24,14762 & 27 & 55,74108 & 0,00000005 \\
\hline OP_EF & 14,87701 & 1 & 34,43333 & 27 & 11,66542 & 0,00202864 \\
\hline OP_GR & 33,69606 & 1 & 43,61428 & 27 & 20,85999 & 0,00009742 \\
\hline OP_AV & 19,77159 & 1 & 78,09048 & 27 & 6,836083 & 0,01443629 \\
\hline OP_AP & 37,99031 & 1 & 60,14762 & 27 & 17,05368 & 0,00031384 \\
\hline OP_OC & 0,102627 & 1 & 51,69048 & 27 & 0,053606 & 0,81864852 \\
\hline IMP_AMB & 0,032184 & 1 & 0,933333 & 27 & 0,931034 & 0,34315774 \\
\hline AT_AG & 0,651724 & 1 & 5,9 & 27 & 2,982466 & 0,09559657 \\
\hline AT_EG & 0,410509 & 1 & 30,76191 & 27 & 0,360307 & 0,55334079 \\
\hline AT_EF & 0,119704 & 1 & 47,32857 & 27 & 0,068289 & 0,79582763 \\
\hline AT_CS & 8,312808 & 1 & 34,92857 & 27 & 6,425852 & 0,01735157 \\
\hline AT_RS & 1,915271 & 1 & 63,25714 & 27 & 0,817494 & 0,37391102 \\
\hline AT_OC & 0,053202 & 1 & 87,25714 & 27 & 0,016462 & 0,89885813 \\
\hline AT_AV & 0,973563 & 1 & 11,23333 & 27 & 2,340018 & 0,13772090 \\
\hline AT_SE & 0,262726 & 1 & 21,04762 & 27 & 0,337026 & 0,56636524 \\
\hline AT_PE & 0,079475 & 1 & 41,1619 & 27 & 0,052131 & 0,82111615 \\
\hline NEC_AC & 0,02775 & 1 & 2,661905 & 27 & 0,281476 & 0,60007268 \\
\hline NEC_AP & 0,781773 & 1 & 16,52857 & 27 & 1,277054 & 0,26838702 \\
\hline NEC_CA & 0,094581 & 1 & 18,45714 & 27 & 0,138358 & 0,71282226 \\
\hline NEC_CE & 0,611002 & 1 & 4,147619 & 27 & 3,977473 & 0,05630019 \\
\hline NEC_EA & 1,844992 & 1 & 24,3619 & 27 & 2,044782 & 0,16419959 \\
\hline NEC_PE & 0,923645 & 1 & 23,21428 & 27 & 1,074271 & 0,30917692 \\
\hline NEC_PLE & 0,119704 & 1 & 3,328571 & 27 & 0,970993 & 0,33318117 \\
\hline NEC_PEA & 0,032184 & 1 & 0,933333 & 27 & 0,931034 & 0,34315774 \\
\hline NEC_CC & 0,362726 & 1 & 38,94762 & 27 & 0,251456 & 0,62011635 \\
\hline & & & & & \\
\hline
\end{tabular}

Com análise de cluster entre estas variáveis, pode-se observar dois clusters distintos apresentados na Figura 11. O cluster 1 é formado por 14 casos, sendo caracterizado por discordar totalmente ou em partes sobre as variáveis de consumo de água, energia, geração de águas pluviais, efluentes líquidos e resíduos sólidos como aspectos de um condomínio que não geram problemas ambientais. Destaca-se que este grupo é formado por $78,57 \%$ de respondentes do sexo masculino. Em relação ao nível de escolaridade este grupo é formado por $57,16 \%$ de pessoas com nível de graduação e pós-graduação, o que demonstra, um certo contra-senso, mesmo tendo um nível alto de formação a percepção ambiental é relativamente baixa.

O segundo cluster é formado por 15 casos, sendo caracterizado por apresentar uma boa conscientização sobre os principais aspetos ambientais de um condomínio, porém ainda continuando com uma atitude relativamente baixa, quanto à realização de coleta seletiva. Este grupo também tem uma maior quantidade de homens, porém apresenta uma maior qualificação 
$73,33 \%$ formado por graduados e pós-graduados e $20 \%$ com nível superior completo. Contudo, pode-se estabelecer que o cluster 2 poderia ser denominado como condôminos conscientes.

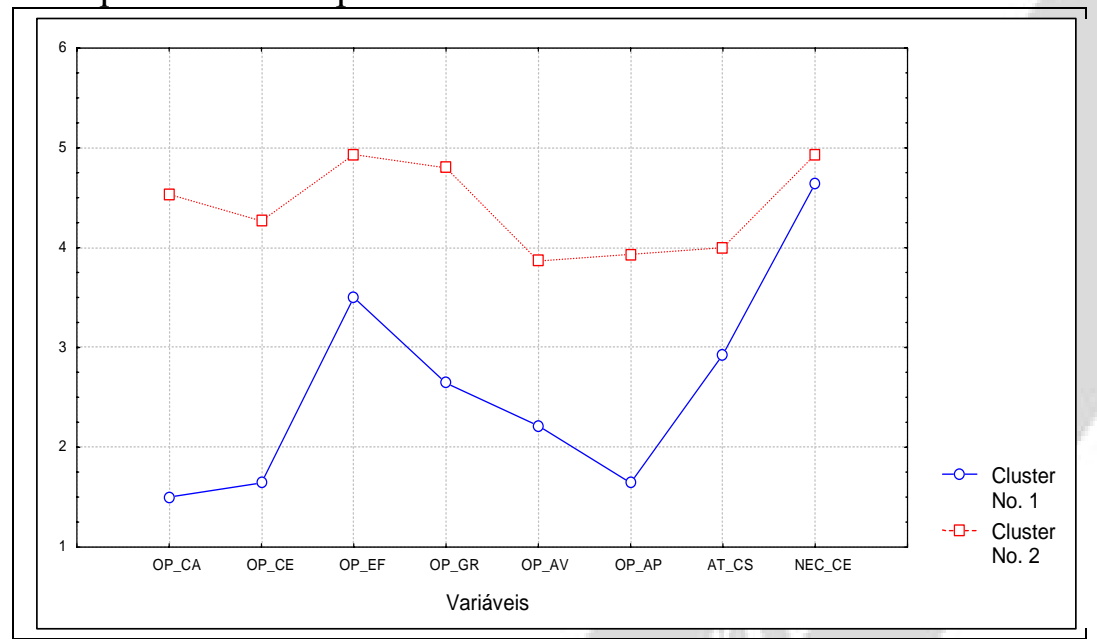

Figura 11 - Análise de Cluster dos condôminos

Tabela 5 - Características dos Clusters formados

\begin{tabular}{|c|c|c|c|c|c|c|}
\hline \multirow{2}{*}{ Variáveis } & \multicolumn{3}{|c|}{ Cluster 1 } & \multicolumn{3}{c|}{ Cluster 2 } \\
\cline { 2 - 6 } & Média & Desvio padrão & Variância & Média & $\begin{array}{c}\text { Desvio } \\
\text { padrão }\end{array}$ & Variância \\
\hline OP_CA & 1,500 & 1,401 & 1,962 & 4,533 & 0,516 & 0,267 \\
\hline OP_CE & 1,643 & 1,277 & 1,632 & 4,267 & 0,458 & 0,210 \\
\hline OP_EF & 3,500 & 1,605 & 2,577 & 4,933 & 0,258 & 0,067 \\
\hline OP_GR & 2,643 & 1,781 & 3,170 & 4,800 & 0,414 & 0,171 \\
\hline OP_AV & 2,214 & 1,805 & 3,258 & 3,867 & 1,598 & 2,552 \\
\hline OP_AP & 1,643 & 1,646 & 2,709 & 3,933 & 1,335 & 1,781 \\
\hline AT_CS & 2,929 & 1,492 & 2,225 & 4,000 & 0,655 & 0,429 \\
\hline NEC_CE & 4,643 & 0,497 & 0,247 & 4,933 & 0,258 & 0,067 \\
\hline
\end{tabular}

\section{CONSIDERAÇÕES FINAIS}

Os condomínios horizontais fechados refletem a idéia de planejamento urbano e qualidade de vida, no entanto a vertente ambiental pode não estar inclusa no "pacote" vendido pelas imobiliárias e ainda, estar ausente na percepção dos condôminos. Destaca-se ainda, que muitos impactos ambientais significativos de um condomínio são ocasionados pela ausência de consciência e atitude inadequada dos condôminos frente ao gerenciamento destes.

Assim, o presente estudo objetivou analisar a percepção ambiental de um condomínio horizontal fechado, localizado no bairro de Nova Parnamirim, região da grande Natal, frente a consciência e atitude relacionadas aos aspectos e impactos de um condomínio, além de analisar a aceitação 
quanto à implementação de práticas de gestão ambiental voltadas aos aspectos significativos identificados no condomínio, que resultem em uma convivência ambiental sustentável.

Os resultados apontam que o nível de consciência em muitos casos é mediano, bem como a atitude pró-ativa diante dos bens ambientais. No entanto, quando um recurso ambiental relacionase com o aspecto financeiro, como no caso da energia, notadamente há um maior número de pessoas empenhadas em reduzir os gastos. De acordo com os resultados obtidos, $37,93 \%$ das pessoas estão preocupadas em economizar água, enquanto $72,41 \%$ estão preocupadas com a energia. Isso acontece porque a conta de água representa um custo irrisório diante dos altos custos de energia.

Destaca-se ainda, que não foi observada uma correlação representativa entre consciência e atitude na maioria das variáveis representantes dos aspectos ambientais significativos, no caso, consumo de água e energia e a geração de efluentes e resíduos.

Os programas de gestão ambiental na maioria dos casos foram aceitos, todavia, quando relacionados a custos financeiros muitos condôminos (69\%) mudaram de idéia. O grupo Gestão Ambiental (GA) aponta que há uma carência de programas ambientais no condomínio, como por exemplo, a coleta seletiva que, apesar de haver uma coleta semanal, menos da metade $(37,93 \%)$ dos condôminos fazem a separação dos materiais. Ainda que os grupos tenham apontado divergências entre a consciência e as atitudes, existe uma considerável aceitação quanto à implementação de programas ambientais.

A partir deste diagnóstico, sugere-se que as ações ambientais sejam postas em prática de modo a resultar em uma harmonia sócio-ambiental, melhorando, assim, a qualidade de vida dos condôminos e o meio ambiente como um todo.

\section{REFERÊNCIAS}

Abreu, C (2009). Empreendimentos sustentáveis: a saída para o planeta. Disponível em: http://www.atitudessustentaveis.com.br/atitudes-sustentaveis/empreendimentos-sustentaveissaida-planeta/.

Almeida, M. C; Filho, O. M. C. (2006). Contribuição para a identificação de aspectos ambientais e impactos significativos na gestão da construção de edificações urbanas. Simpósio de Engenharia de Produção, Bauru, SP, Brasil, 6 a 8 de Novembro de 2006.

Associação Brasileira de Normas Técnicas. (2004). NBR ISO 14001. Sistema da gestão ambiental - Requisitos com orientações para uso. Rio de Janeiro: ABNT.

Becker, W. E. Statistics for business and economics. Cincinnati: International Thonson Publishing, 1994, p. 260.

Braga, B; Conejo, J. G. (2005). Introdução à engenharia ambiental. São Paulo: Pearson Prentice Hall, 318p.

Brasil. CONAMA - Conselho Nacional de Meio Ambiente (1986). Resolução $n^{o}$ 001, de 23.01.1986, trata do uso e implementação da Avaliação de Impacto Ambiental como um dos instrumentos da Política Nacional do Meio Ambiente. Disponível em: http://www.mma.gov.br/port/conama/res/res86/res0186.html. Acesso em: ago/2009. 
Carvalho, A. P; Silva, D. G. K. C. (2009, jan./abr). Estudo sobre a percepção ambiental em laboratórios de análises clínicas. Revista Engenharia Ambiental - Pesquisa e Tecnologia. Editora Unipinhal. Espírito Santo do Pinhal - SP , v. 6, n. 1, p. 154-168.

Chiamenti, A. M. M. (2003). Gestão ambiental na agricultura: um estudo sobre fatores associados à conscientização ambiental em estudantes de uma escola agrotécnica. 120p. Dissertação (Mestrado em Engenharia de Produção) - Universidade Federal do Rio Grande do Norte.

Duarte, R. (2009). População de Parnamirim cresce três vezes mais do que a de Natal. Diário de Natal, Natal-RN, 18 ago. 2009. Notícias. Disponível em: http://www.dnonline.com.br/ver_noticia/16452/

Kvanli, A. H.; Guynes, C. S. and Pavur, R. J. (1996). Introduction to business statistic - a computer integrated data analysis approach. New York: West Publishing Company. p. 267.

Souza, M. P. (2000). Instrumentos de Gestão Ambiental - fundamentos e prática. Editora Riani Costa. São Carlos. 108p.

Walman, M; Schneider, D. (2000). Guia ecológico doméstico. São Paulo: Contexto. 175p. 